\title{
Клінічний випадок хвороби Кастлемана з ураженням печінки та селезінки
}

\author{
Я.І. Виговська, І.Й. Євстахевич, 3.В. Масляк, М.М. Семерак, Ю.Л. Євстахевич, Н.В. Книш, Х.Р. Тхір \\ ДУ «Інститут патології крові та трансфузійної медицини НАМН України», Львів, Україна
}

\begin{abstract}
Анотація. Хвороба Кастлемана (ангіофолікулярна гіперплазія лімфатичних вузлів) - рідкісне доброякісне лімфопроліферативне захворювання з ризиком трансформації в лімфому. Частота захворювання становить 1 випадок на 100 тис. населення. Виділяють 4 клініко-морфологічні варіанти захворювання: гіаліново-васкулярний локальний, плазмоклітинний локальний, мультицентричний та HHV-8-асоційований плазмобластний. Найбільш частим серед них $\epsilon$ гіаліново-васкулярний тип (70\% випадків). У статті представлене власне спостереження хвороби Кастлемана (гіаліново-васкулярний тип) у хворої зі збільшенням селезінки та цитопенією внаслідок гіперспленізму. Висвітлені складність діагностики, результат хірургічного лікування (видалення селезінки) та спостереження за перебігом хвороби протягом 16 років.
\end{abstract}

Ключові слова: хвороба Кастлемана, діагностика, хірургічне лікування.

\section{Вступ}

Хвороба Кастлемана, також відома як ангіофолікулярна лімфома або гігантська гіперплазія лімфатичних вузлів, являє собою доброякісне лімфопроліферативне захворювання. Вперше описана в 1954 р. патологоанатомом Бенжаміном Кастлеманом 3 клініки штату Массачусетс (США). Як окрема нозологічна одиниця виділена в 1956 р. під назвою «хвороба Кастлемана» [1, 2]. Прояви захворювання $\epsilon$ неоднорідними і можуть характеризуватися тривалим безсимптомним перебігом з локальною лімфаденопатією або дифузною лімфаденопатією з тяжкими системними проявами. Хвороба Кастлемана може асоціюватися з амілоїдозом, аутоімунними процесами, як наслідок імунного конфлікту самої хвороби, а також з лімфопроліферативними захворюваннями. Поширеність хвороби вивчена недостатньо - близько 1 випадку на 100 тис. населення, однаково часто хворіють чоловіки і жінки. Хвороба Кастлемана відмічається у будь-якому віці, найчастіше до 35 років [3-5].

На даний час виділяють 4 гістопатогенетичні типи хвороби: гіаліново-васкулярний, плазмоклітинний, мультицентричний, а також HHV-8-асоційований плазмобластний [6-8]. Найбільш поширеним $\epsilon$ гіаліново-васкулярний локальний тип хвороби Кастлемана, який виявляють в $>70 \%$ випадків хвороби. Симптоми, що проявляються у пацієнтів, відрізняються залежно від місця ураження. Хворі з лімфаденопатією середостіння та черевної порожнини переважно не пред'являють скарг. Діагностика має характер випадкового виявлення під час рентгенологічних і сонографічних обстежень, хірургічних втручань з приводу інших захворювань, або пацієнт звертається до лікаря зі скаргами на локальне збільшення периферичних лімфовузлів чи симптоми стиснення органів або судин. Ураження при гіаліново-васкулярному локальному типі представлені у вигляді поодиноких утворень з інтенсивним посиленим контрастуванням при комп'ютерній томографії чи позитронно-емісійній комп'ютерній томографії. Оскільки це не дає можливості провести диференційну діагностику зі злоякісними процесами, діагноз хвороби Кастлемана встановлюють шляхом ексцизійної біопсії лімфатичних вузлів. Висока ймовірність виділити з лімфовузла тільки здорові клітини робить недоцільним застосування з діагностичною метою аспіраційної біопсії $[7,8]$.

\section{Клінічний випадок}

Пацієнтка Л., 1979 р.н. Вперше обстежена гематологом у грудні 2004 р. Скарги на загальну слабкість, підвищену пітливість, біль в лівому підребер'ї.

В аналізах крові - лейкопенія з нейтропенією. На момент обстеження виявлено лише збільшення розмірів селезінки.

Загальний аналіз периферичної крові: гемоглобін - 120 г/л, еритроцити $-3,9 \cdot 10^{12} /$ л, лейкоцити $-3,5 \cdot 10^{9} /$ л, тромбоцити - 158.10\%/л, швидкість осідання еритроцитів (ШОЕ) - 5 мм/год. Лейкограма: паличкоядерні нейтрофіли - 9\%, сегментоядерні нейтрофіли - 38\%, моноцити - 5\%, лімфоцити - 46\%, лімфоїдні клітини - $2 \%$.

Пункційна біопсія кісткового мозку: препарат гіперклітинний, переважають гранулоцити різних стадій дозрівання, нормобластичний тип еритропоезу, мегакаріоцити діяльні.

Захворювання кровотворної системи у пацієнтки не встановлено, однак продовжено спостереження гематологом. 3 роками в аналізі крові відмічено поглиблення нейтропенії.

У 2008 р. пацієнтка обстежена в гематологічній клініці «Charité» (Берлін, Німеччина), висновок: «В трепанаті кульшової кістки виявлено паратрабекулярну інфільтрацію клітинами В-клітинної лімфоми, очевидно, маргінальної зони. До диференційної діагностики слід включити фолікулярну лімфому. Виходячи з даних аналізу, клініки та даних обстеження, є підозра на наявність селезінкової лімфоми маргінальної зони. Не виявлено збільшених периферичних лімфатичних вузлів, а також лімфатичних вузлів в грудній клітиі та черевній порожнині. Немає доказів про попередній вірусний гепатит С. Виражена спленомегалія. Тривалий час перебіг хвороби був без клінічних проявів. На основі спленомегалії розвинулася периферична иитопенія. Цитогенетичних змін у хворої не виявлено. Узв'язкуз вираженою спленомегалією, периферичною читопенією, як наслідок гіперспленізму, доцільна спленектомія. Крім того, спленектомія $\epsilon$ методом лікування при селезінковій лімфомі маргінальної зони. Гістологічне дослідження селезінки буде підтвердженням діагнозу. Перед спленектомією необхідно провести вакцинацію».

Для проведення спленектомії пацієнтку госпіталізовано в хірургічне відділення ДУ «Інститут патології крові та трансфузійної медицини НАМН України», медична карта від 14.01.2008 р. № 328.

Аналіз крові при поступленні: гемоглобін - 121 г/л, еритро-

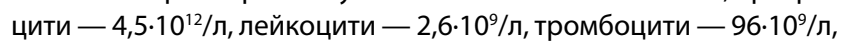
паличкоядерні нейтрофіли - 3\%, сегментоядерні нейтрофіли $62 \%$, моноцити - 4\%, лімфоцити - 31\%, ШОЕ - 7 мм/год.

17.01.2008 р. виконано спленектомію та біопсію печінки. Операцію проводили через верхній серединний лапаратомний розріз. При ревізії: селезінка без периспленіту, великих розмірів - 28х18х10 см. Виявлено ланцюги збільшених лімфатичних вузлів діаметром 0,5x1,0 см вздовж селезінкової артерії. Печінка без макроскопічних змін, не збільшена. Виконано біопсію лівої частки печінки. Проведено спленектомію із лігуванням судин селезінки. Селезінка масою 1300 г, на розрізі в паренхімі наявні численні білясті включення. Операцію завершено прискіпливим гемостазом та пошаровим швом рани.

Перебіг післяопераційного періоду - без ускладнень. 
Загальний аналіз крові після операції: гемоглобін - 121 г/л, еритроцити - 4,6·1012/л, лейкоцити - 18,0·10\%/л, тромбоцити $142 \cdot 10 \%$ л, паличкоядерні нейтрофіли - 7\%, сегментоядерні нейтрофіли - 90\%, моноцити - 1\%, лімфоцити - 2\%, ШОЕ 18 мм/год. Поступово показники периферичної крові нормалізувалися.

Препарати селезінки, печінки, лімфатичних вузлів, кісткового мозку направлені в лабораторію «CBLPath» (Мюнстер, Нiмеччина). Результати патогістологічного дослідження: «1. Печінка: Хвороба Кастлемана, гіаліново-васкулярний тип, ураження печінки. У препараті (фарбування гематоксиліном-еозином) виявлено помірні вогнищеві округлі включення в незміненій паренхімі печінки. Відзначено два невеликих лімфоїдних скупчення 3 атрофічним зародковим иентром, оточених шарами дрібних лімфоцитів у вигляді «цибульної луски». 2. Селезінка: хвороба Кастлемана, гіаліново-васкулярний тип, ураження селезінки. У препараті виявлено багато великих реактивних, а також малих атрофічних лімфоїдних фолікулів, деякі фолікули оточені шарами маленьких лімфочитів, розташованих у вигляді «цибульної луски». Інколи відзначається також гіалінова речовина в зародковому центрі. Наявна підвищена васкуляризація з проліферачією капілярів та гіперплазією ендотелію в червоній пульпі. 3. Лімфатичний вузол: хвороба Кастлемана, гіалінововаскулярний тun. Архітектура вузла змінена збільшеною кількістю лімфоїдних фолікулів по всій паренхімі. Зародкові чентри погано сформовані та невеликі з атрофічними $C D 23^{+}$фолікулярними дендритними клітинами, оточеними шарами дрібних лімфоцитів, розташованих у вигляді «цибульної луски». Іноді дрібні капіляри в зародковому чентрі обволікаються колагеном або оточені гіаліновою речовиною. Спостерігається посилення міжфолікулярної васкуляризачії з проліферацією капілярів та гіперплазією ендотелію. Плазматичних клітин мало. 4. Кістковий мозок: бionmam кісткового мозку злегка гіперклітинний, як для віку пачієнтки (10-20\% жиру). Представлено множинні паратрабекулярні і непаратрабекулярні лімфоїдні скупчення, що складаються з дрібних клітин з округлими ядрами, згущеного (конденсованого) хроматину, нечітких ядерець і мізерної иитоплазми; займають близько 5-10\% клітин кісткового мозку. Еритроцитарний паросток і дозріваючі мієлоїдні елементи представлені в нормальній пропориії і формі дозрівання. Мегакаріоцити наявні в нормальній кількості. Виявлені розкидані плазматичні клітини. Гранульом та метастатичної карциноми не виявлено. Кісткові трабекули не змінені. Імунопероксидазне дослідження препарату показало, що лімфоїдні скупчення змішано-клітинні: $\mathrm{CD}^{+}$(Т-клітинний маркер) і CD20+ (В-клітинний маркер) з легким переважанням CD3+. На основі иих даних встановлено діагноз: хвороба Кастлемана, гіаліново-васкулярний тип».

Протягом 12 років пацієнтка почувалася добре, скарг не було. Періодично здавала аналізи крові, які були без відхилень від норми. В останній рік виявлено незначне підвищення рівня лейкоцитів.

Аналіз крові від 08.05.2020 р.: гемоглобін - 136 г/л, еритроцити $-4,7 \cdot 10^{12} /$ л, лейкоцити $-8,9 \cdot 10^{9} /$ л, тромбоцити $289.10 \%$, паличкоядерні нейтрофіли - $2 \%$, сегментоядерні нейтрофіли - 70\%, моноцити - 5\%, еозинофіли - 2\%, лімфоцити - $21 \%$.

Враховуючи можливість трансформації хвороби Кастлемана в неходжкінську лімфому, пацієнтку обстежено в ДУ «Інститут патології крові та трансфузійної медицини НАМН України».

При обстеженні загальний стан хворої хороший, скарг немає. Периферичні лімфатичні вузли не збільшені. Нижній край печінки на рівні реберної дуги.

Аналіз крові від 09.11.2020 р.: гемоглобін - 139 г/л, ери-

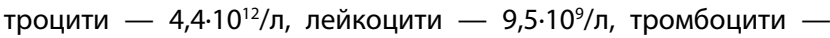
473.10\%, паличкоядерні нейтрофіли - 1\%, сегментоядерні нейтрофіли - 51\%, моноцити - 6\%, еозинофіли - $1 \%$, базофіли - $2 \%$, лімфоцити - 39\%.

Імунофенотипування клітин периферичної крові методом проточної цитометрії від 12.11.2020 р.: CD3 - 84,3\%, CD4 $42,7 \%$, CD5 - 83,1\%, CD7 - 82,7\%, CD8 - 37,9\%, CD10-0,6\%,
CD 19 - 15,2\%, CD20 - 15,2\%, CD22 - 11,2\%, CD23 - 10,8\%, CD38 - 57,0\%, CD79b - 9,2\%, CD23/5 - 4,4\%, CD 19/5 - 5,8\%, CD38/5 - 43,8\%, CD 19/23 - 10,9\%, CD38/23 - 10,5\%, CD 19/38$12,5 \%, C D 20 / 19-15,2 \%, C D 22 / 19-11,1 \%, C D 22 / 20-11,0 \%$, $\mathrm{CD} 7 / 5-77,2 \%, \mathrm{CD} 3 / 4-42,5 \%, \mathrm{CD} 3 / 8-36,4 \%$. Висновок: $\mathrm{CD} 4 / 8-0,1 \%, \mathrm{CD} 10 / 19-0,6 \%, \mathrm{CD} 79 \mathrm{~b} / 19-8,9 \%$.

Таким чином, Т-лімфоцити становлять $84 \%$, В-лімфоцити $12 \%$, серед них 9,2\% CD79b лімфоцитів, характерних для клітин лімфоми зони мантії.

Гістологічний висновок трепанобіоптату: кістковий мозок нормоцелюлярний (55\%), клітинний склад поліморфний, лейкоеритробластичне співвідношення збережене; визначаються клітини гранулоцитарного паростка, еритроїдні острівці збережені, мегакаріоцити 0-3 у полі зору, без ознак дисплазії. Морфологічних ознак лімфопроліферативного захворювання не виявлено.

У даний час стан хворої залишається задовільним. Незважаючи на наявність в печінці та лімфатичних вузлах змін, характерних для хвороби Кастлемана, після видалення селезінки - основного місця ураження - протягом 12 років прогресії хвороби не відмічено, також не виявлено ознак трансформації хвороби Кастлемана в неходжкінську лімфому.

\section{Обговорення}

Хвороба Кастлемана - дуже рідкісне захворювання, діагностика якого $€$ складною. У обстеженої нами пацієнтки виявлено варіант хвороби, що відмічається найчастіше і має індолентний перебіг. Протягом 4 років єдиними проявами хвороби були збільшення розмірів селезінки і зумовлена гіперспленізмом цитопенія. У трепанобіоптаті кісткового мозку, що досліджували в клініці «Charité», виявлено популяцію клітин, яку початково морфологи розцінили як ознаку лімфоми клітин маргінальної зони. Наростання гіперспленізму та необхідність встановлення його природи стали підставою для проведення спленектомії з біопсією печінки, регіонарних лімфовузлів та повторної трепанобіопсії кісткового мозку. На основі гістологічного дослідження отриманого матеріалу встановлено діагноз хвороби Кастлемана, причому в біоптаті кісткового мозку, проведеному повторно, патологічних змін не виявлено.

Особливістю гіаліново-васкулярного типу хвороби Кастлемана $\epsilon$ висока ефективність оперативного видалення одного або кількох лімфовузлів, а також видалення селезінки. Після спленектомії пацієнтка протягом 12 років почувається добре, клінічні прояви хвороби Кастлемана відсутні, що підтверджує дані про ефективність хірургічного підходу при лікуванні гіалінововаскулярного локального типу хвороби. Разом з тим ураження печінки, селезінки та лімфовузла у цієї пацієнтки, а також можливість розвитку неходжкінської лімфоми при інших варіантах хвороби Кастлемана спонукали нас провести дослідження популяцій лімфоцитів периферичної крові за допомогою проточної цитометрії з метою виявлення патологічного клону лімфоїдних клітин. У популяції В-лімфоцитів, яка загалом була в межах норми, виявлено 9,2\% CD79b клітин, притаманних зоні мантії. На нашу думку, ця субпопуляція лімфоцитів $\epsilon$ недостатньою, щоб вважати їі патологічним клоном і говорити про ризик трансформації хвороби Кастлемана в лімфому за відсутності клінічних ознак. Разом з тим аналіз субпопуляційного складу лімфоцитів периферичної крові пацієнтки в динаміці дозволить моніторувати їі стан і ризик розвитку рецидиву хвороби Кастлемана.

\section{Висновок}

Представлений клінічний випадок свідчить про труднощі в діагностиці хвороби Кастлемана, значну ефективність хірургічного лікування, а саме видалення основного місця ураження при гіаліново-васкулярному варіанті, а також потребу у дослідженні її патогенезу для налагодження моніторингу хвороби і призначення патогенетично обґрунтованої терапії для конкретного пацієнта 3 хворобою Кастлемана.

\section{Фінансування}

Дослідження профінансоване коштом авторів. 


\section{Конфлікт інтересів}

Автори декларують відсутність конфлікту інтересів щодо цього рукопису.

\section{Згода на публікацію}

Усі автори дали згоду на публікацію цього рукопису.

\section{Список використаної літератури}

1. Castleman B., Thowne V.W. (1954) Case records of the Massachusetts General Hospital Weekly Clinicopathological Exercises. New Engl. J. Med., 250: 26-30. D0l: 10.1056/ NEJM195401072500107

2. Castleman B., Iverson L., Menendez V.P. (1956) Localized mediastinal lymphnode hyperplasia resembling thymoma. Cancer, 9(4):822-830.D01:10.1002/1097-0142(195607/08)9:4<822:aidcncr2820090430>3.0.c0;2-4.

3. Skiniotis G., Boulanger M.J., Garcia K.C. et al. (2005) Signaling conformations of the tall cytokine receptor gp130 when in complex with IL-6 and IL-6 receptor. Nat. Struct. Mol. Biol., 12(6): 545-551. D0I: 10.1038/nsmb941; PMID: 15895091.

4. Моисеев В.С., Мартынов А.И., Мухин Н.А. (2018) Внутренние болезни. Том 2, 3-е изд., перераб. и доп. ГЕОТАР-Медиа, Москва, 958 с.

5. Меликян А.Л., Егорова Е.К., Ковригина А.М. и др. (2015) Клинико-морфологические особенности различных вариантов болезни Кастельмана. Тер. архив, 87(7): 64-71.

6. Малаева Е.Г. (2016) Учебно-методический комплекс по дисциплине «Внутренние болезни» для 6 курса. ГомГМУ, Гомель.

7. Меликян А.Л., Егорова Е.К. (2016) Болезнь Кастлемана (обзор литературы). Онкогематология, 11: 8-20. DOI: 10.17650/1818-8346-2016-11-2-8-20

\section{Відомості про авторів:}

Виговська Ярослава Іллівна — доктор медичних наук, професор, головний науковий співробітник ДУ «Інститут патології крові та трансфузіййої медицини НАМН України», Львів, Україна. ORCID ID: 0000-0003-1555-1828

Євстахевич Ігор Йосифович - доктор медичних наук, завідувач відділення загальної та гематологічної хірургії, старший науковий співробітник ДУ «Інститут патології крові та трансфузійної медицини НАМН України», Львів, Україна.

Масляк Звенислава Володимирівна — завідувач відділення гематологї̈, доктор медичних наук, старший науковий співробітник ДУ «Інститут патології крові та трансфузійної медицини НАмН України», Львів, Україна.

Семерак Максим Михайлович — науковий співробітник відділення загальної та гематологічної хірургї ДУ «Інститут патології крові та трансфузійної медицини НАМН України», Львів, Україна. Євстахевич Юрій Львович — кандидат медичних наук, провідний науковий співробітник, старший науковий співробітник ДУ «Інститут патології крові та трансфузійної медицини НАМН України», Львів, Україна.

Книш Наталія Володимирівна — кандидат медичних наук, старший науковий співробітник, лікар-гематолог відділення гематології ДУ «Інститут патології крові та трансфузійної медицини НАМН України», Львів, Україна. ORCID ID: 0000-0002-1850-7083.

Тхір Христина Романівна — молодший науковий співробітник відділення гематології ДУ «Інститут патології крові та трансфузійної медицини НАМН України», Львів, Україна.

\section{Адреса для кореспонденції:}

Книш Наталія Володимирівна

79044, Львів, вул. Генерала Чупринки, 45

E-mail: nataliya.knysh27@gmail.com
8. Опанасенко М.С., Конік Б.М., Ліскіна І.В. та ін. (2020) Клінічний випадок хвороби Кастлемана. Укр. пульмонол. журнал, 3: 63-67. D0I: 10.31215/2306-4927-2020-109-363-67

\section{Clinical case of Castleman disease with liver and spleen affection}

Ya.I. Vyhovska, I.Yo. Yevstakhevych, Z.V. Maslyak, M.M. Semerak, Yu.L. Yevstakhevych, N.V. Knysh, Kh.R. Thir

State Institution «Institute of Blood Pathology and Transfusion Medicine of the NAMS of Ukraine», Lviv, Ukraine

Abstract. Castleman disease (angiofollicular hyperplasia of the lymph nodes) is a rare benign lymphoproliferative disease with a risk of transformation into lymphoma. Incidence 1 case per 100 thousand population. There are 4 of clinical and morphological types of the disease: hyaline-vascular local, plasma cell local, multicentric, HHV-8-associated plasmoblastic. The most common among them is the hyaline-vascular type ( $70 \%$ of cases). The article presents our own observation of Castleman disease (hyaline-vascular type) in a patient with enlarged spleen and cytopenia due to hypersplenism. The complexity of diagnosis, the result of surgical treatment (removal of the spleen) and monitoring of the disease for 16 years are highlighted.

Key words: Castleman disease, diagnosis, surgical treatment.

\section{Information about the authors:}

Vyhovska Yaroslava I. - Doctor of Medical Science, PhD, MD, Professor, Chief Researcher of the SI «Institute of Blood Pathology and Transfusion Medicine of the NAMS of Ukraine», Lviv, Ukraine. ORCID ID: 0000-0003-1555-1828

Yevstakhevych Ihor Yo. — Doctor of Medical Sciences, Head of the Department of General and Hematological Surgery, Senior Research Fellow of the SI «Institute of Blood Pathology and Transfusion Medicine of the NAMS of Ukraine», Lviv, Ukraine.

Maslyak Zvenyslava V. — Doctor of Medical Science, PhD, MD, Head of the Department of Hematology of the Sl «Institute of Blood Pathology and Transfusion Medicine of the NAMS of Ukraine», Lviv, Ukraine.

Semerak Maksym M. — Research Fellow, Department of General and Hematological Surgery of the SI «Institute of Blood Pathology and Transfusion Medicine of the NAMS of Ukraine», Lviv, Ukraine. Yevstakhevych Yuriy L. - Candidate of Medical Sciences, Leading Researcher of the Department of General and Hematological Surgery of the SI «Institute of Blood Pathology and Transfusion Medicine of the NAMS of Ukraine», Lviv, Ukraine.

Knysh Nataliia V. — PhD, Senior Researcher, haematologist, Department of Hematology of the SI «Institute of Blood Pathology and Transfusion Medicine of the NAMS of Ukraine», Lviv, Ukraine. ORCID ID: 0000-0002-1850-7083

Thir Khrystyna R. — Junior Researcher at the Department of Hematology of the SI «Institute of Blood Pathology and Transfusion Medicine of the NAMS of Ukraine», Lviv, Ukraine.

Address for correspondence:

Nataliia Knysh

79044, Lviv, General Chuprynky str., 45

E-mail: nataliya.knysh27@gmail.com 